\title{
Factors Affecting Pathological Complete Response After Neoadjuvant Chemotherapy in Operable Primary Breast Cancer
}

\author{
Yanli Lv, Yi Li, Weimin Mu and Hui Fu \\ Breast Center, Shunyi District Health Care Hospital for Women and Children of Beijing, Beijing 101300, P.R. China
}

\begin{abstract}
Objective: To investigate factors influencing pathological response to neoadjuvant chemotherapy (NAC) in operable primary breast cancer.

Study Design: Descriptive study.

Place and Duration of Study: Breast Center, Shunyi District Health Care Hospital for Women and Children of Beijing, Beijing 101300, P.R. China, from January 2009 to December 2017.

Methodology: Two hundred and sixty-one operable primary invasive breast cancer patients treated with NAC were included in this observational study. Pathological complete response ( $\mathrm{PCR}$ ) was defined as no residual invasive disease in either the breast or the axillary lymph nodes, with non-invasive breast residuals permitted (ypTO/is ypNO). Factors affecting pCR were subjected to univariate and multivariate analysis.
\end{abstract}

Results: Seventy-six patients (29.1\%) achieved pCR after NAC. Tumor size, histological grade, status of estrogen receptor (ER) and progesterone receptor (PgR), expression of human epidermal growth factor receptor 2 (HER2) and Ki67, axillary lymph node status, and chemotherapy regimen were all significantly associated with $\mathrm{pCR}$ in univariate analysis (all $p<0.05$ ). In multivariate analysis, high histological grade, negative HR status and lymph nodes, positive HER2 status, and taxane-based regimens were independent predictive factors of pCR. Patients with HER2-positive tumors were more sensitive to NAC regimen including trastuzumab.

Conclusion: In this study, breast cancer patients with high histological grade, negative HR status and lymph nodes, positive HER2 status, as well as taxane-based regimens were significantly associated with achieving pCR with NAC.

Key Words: Breast neoplasms, Neoadjuvant therapy, Surgery, Pathology.

How to cite this article: Lv Y, Li Y, Mu W, Fu H. Factors Affecting Pathological Complete Response After Neoadjuvant Chemotherapy in Operable Primary Breast Cancer. J Coll Physicians Surg Pak 2020; 30(04):389-393. DOI: https://doi.org/10.29271/jcpsp.2020.04.389.

\section{INTRODUCTION}

Neoadjuvant chemotherapy (NAC) is an equivalent option to adjuvant chemotherapy by clinical trials in terms of breast cancer survival. Additionally, it provides a chance to evaluate the response of breast tumors to chemotherapy regimen. Thus, NAC has several advantages. These include initiation of systematic treatment as soon as possible towards primary and potential metastases lesions; reduction of tumor size to improve the chance of breast conserving surgery; identification and termination of ineffective treatment, and replacement of more effective therapy timely; providing platform for research through clinical monitoring, as well as obtaining blood and tissue specimens at different times during neoadjuvant therapy. ${ }^{1,2}$

Correspondence to: Dr. Yanli Lv, Breast Center, Shunyi District Health Care Hospital for Women and Children of Beijing, No.1 Shunkang Road, Shunyi District, Beijing 101300, P.R.China

E-mail:lv.yanli@163.com

Received: March 19, 2020; Revised: April 09, 2020;

Accepted: April 20, 2020

DOI: https://doi.org/10.29271/jcpsp.2020.04.389
NSABP B-18 trial indicated that patients whose tumors achieved pathological complete response ( $p C R$ ) had a better 5 -year DFS, RFS, and survival. ${ }^{3}$ It is a surrogate end-point for survival, and now an approved end-point in accelerated approval of novel chemotherapeutic agents.

Several clinical and pathological factors are known to affect pCR; for instance, tumor size, histological grade, status of ER and PgR, and expression of HER 2 and Ki67. It is widely accepted that tumors with subtypes of HER2-positive and triple negative (TN) show higher $\mathrm{PCR}$ rates, while tumors with luminal A subtype are the least likely to achieve $p C R .{ }^{4,5} \mathrm{As}$ obesity is recognized a risk factor of breast cancer, higher BMI may also be negatively associated with pCR; however, this is still controversial. ${ }^{6,7}$

Recently, there is an increasing focus on peripheral inflammatory indicators, such as neutrophil-to-lymphocyte ratio (NLR), and platelet-to-lymphocyte ratio (PLR). Studies show lower NLR and/or lower PLR might be independent predictor of $\mathrm{pCR}$ either alone or combined. ${ }^{8} \mathrm{~A}$ study conducted in South China suggested that NLR $<2.06$ was associated with desirable $p C R$ rate, and lower NLR was an independent prognostic predictor. ${ }^{9}$ However, the predictive value of inflammatory indicators has notbeen analysed along with other clinicopathological factors in study among breast cancer patients in North China. In this study, the objective was to investigate the factors predicting $\mathrm{PCR}$ in primary breast cancer 
patients receiving preoperative chemotherapy, aimed to provide basis for response evaluation of NAC.

Table I: Patient characteristics.

\begin{tabular}{|c|c|c|}
\hline & $N=261$ & $\%$ \\
\hline $\begin{array}{l}\text { Age (year) } \\
\leq 50 \\
>50\end{array}$ & $\begin{array}{l}128 \\
133\end{array}$ & $\begin{array}{l}49.0 \\
51.0\end{array}$ \\
\hline $\begin{array}{l}\text { BMI } \\
\text { Normal/low weight } \\
\text { Overweight } \\
\text { Obesity }\end{array}$ & $\begin{array}{c}77 \\
109 \\
75\end{array}$ & $\begin{array}{l}29.5 \\
41.8 \\
28.7\end{array}$ \\
\hline $\begin{array}{l}\text { Menopause } \\
\text { Yes } \\
\text { No }\end{array}$ & $\begin{array}{l}124 \\
137\end{array}$ & $\begin{array}{l}47.5 \\
52.5\end{array}$ \\
\hline $\begin{array}{l}\text { Family history of malignancy } \\
\text { Yes } \\
\text { No }\end{array}$ & $\begin{array}{c}41 \\
220\end{array}$ & $\begin{array}{l}15.7 \\
84.3\end{array}$ \\
\hline $\begin{array}{l}\text { Tumor size }(\mathrm{cm}) \\
\leq 2 \\
>2\end{array}$ & $\begin{array}{c}61 \\
200\end{array}$ & $\begin{array}{l}23.4 \\
76.6\end{array}$ \\
\hline $\begin{array}{l}\text { Pathological type } \\
\text { IDC } \\
\text { Other }\end{array}$ & $\begin{array}{c}237 \\
24\end{array}$ & $\begin{array}{c}90.8 \\
9.2\end{array}$ \\
\hline $\begin{array}{l}\text { Grade } \\
\text { I+II } \\
\text { III } \\
\text { Unknown }\end{array}$ & $\begin{array}{c}188 \\
60 \\
13\end{array}$ & $\begin{array}{r}72.0 \\
23.0 \\
5.0\end{array}$ \\
\hline $\begin{array}{l}\text { ER } \\
\text { Negative } \\
\text { Positive }\end{array}$ & $\begin{array}{c}91 \\
170\end{array}$ & $\begin{array}{l}34.9 \\
65.1\end{array}$ \\
\hline $\begin{array}{l}\text { PgR } \\
\text { Negative } \\
\text { Positive }\end{array}$ & $\begin{array}{l}108 \\
153\end{array}$ & $\begin{array}{l}41.4 \\
58.6\end{array}$ \\
\hline $\begin{array}{l}\text { HER2 } \\
\text { Negative } \\
\text { Positive } \\
\text { Unknown }\end{array}$ & $\begin{array}{c}150 \\
104 \\
7\end{array}$ & $\begin{array}{c}57.5 \\
39.8 \\
2.7\end{array}$ \\
\hline $\begin{array}{l}\text { Ki67 } \\
\text { Low expression } \\
\text { High expression } \\
\text { Unknown }\end{array}$ & $\begin{array}{c}44 \\
200 \\
17\end{array}$ & $\begin{array}{c}16.9 \\
76.6 \\
6.5\end{array}$ \\
\hline $\begin{array}{l}\text { Lymph nodes } \\
\text { Negative } \\
\text { Positive } \\
\text { Unknown }\end{array}$ & $\begin{array}{c}96 \\
150 \\
15\end{array}$ & $\begin{array}{r}36.8 \\
57.5 \\
5.7\end{array}$ \\
\hline $\begin{array}{l}\text { Chemotherapy cycles } \\
4 \sim \\
6 \sim \\
8 \sim\end{array}$ & $\begin{array}{c}55 \\
70 \\
136\end{array}$ & $\begin{array}{l}21.1 \\
26.8 \\
52.1\end{array}$ \\
\hline $\begin{array}{l}\text { Chemotherapy regimens } \\
\text { Anthracycline-based } \\
\text { Taxane-based } \\
\text { Combination of anthracycline and taxane }\end{array}$ & $\begin{array}{c}44 \\
106 \\
111\end{array}$ & $\begin{array}{l}16.9 \\
40.6 \\
42.5\end{array}$ \\
\hline $\begin{array}{l}\text { Baseline NLR } \\
<2.1 \\
\geq 2.1\end{array}$ & $\begin{array}{l}130 \\
131\end{array}$ & $\begin{array}{l}49.8 \\
50.2\end{array}$ \\
\hline $\begin{array}{l}\text { Baseline PLR } \\
<150 \\
\geq 150\end{array}$ & $\begin{array}{l}161 \\
100\end{array}$ & $\begin{array}{l}61.7 \\
38.3\end{array}$ \\
\hline $\begin{array}{l}\text { Molecular subtype } \\
\text { Triple negative } \\
\text { HER2-positive (any HR status) } \\
\text { Luminal }\end{array}$ & $\begin{array}{c}44 \\
104 \\
113\end{array}$ & $\begin{array}{l}16.9 \\
39.8 \\
43.3\end{array}$ \\
\hline $\begin{array}{l}\text { Pathological response } \\
\text { pCR } \\
\text { Non-pCR }\end{array}$ & $\begin{array}{c}76 \\
185\end{array}$ & $\begin{array}{l}29.1 \\
70.9\end{array}$ \\
\hline
\end{tabular}

Table II: Association of baseline clinical characteristics with pathological response.

\begin{tabular}{|c|c|c|c|}
\hline & $\begin{array}{c}\text { pCR } \\
(n=76, \%)\end{array}$ & $\begin{array}{c}\text { non-pCR } \\
(n=185, \%)\end{array}$ & p-value \\
\hline $\begin{array}{l}\text { Age (year) } \\
\leq 50 \\
>50\end{array}$ & $\begin{array}{l}33(43.4) \\
43(56.6)\end{array}$ & $\begin{array}{l}95(51.4) \\
90(48.6)\end{array}$ & 0.244 \\
\hline $\begin{array}{l}\text { BMI } \\
\text { Normal/low weight } \\
\text { Overweight } \\
\text { Obesity }\end{array}$ & $\begin{array}{l}29(38.2) \\
25(32.9) \\
22(28.9)\end{array}$ & $\begin{array}{l}48(25.9) \\
84(45.4) \\
53(28.6)\end{array}$ & 0.093 \\
\hline $\begin{array}{l}\text { Menopause } \\
\text { Yes } \\
\text { No }\end{array}$ & $\begin{array}{l}39(51.3) \\
37(48.7)\end{array}$ & $\begin{array}{c}85(45.9) \\
100(54.1)\end{array}$ & 0.430 \\
\hline $\begin{array}{l}\text { Family history of malignancy } \\
\text { Yes } \\
\text { No }\end{array}$ & $\begin{array}{l}12(15.8) \\
64(84.2)\end{array}$ & $\begin{array}{c}29(15.7) \\
156(84.3)\end{array}$ & 0.982 \\
\hline $\begin{array}{l}\text { Tumor size }(\mathrm{cm}) \\
\leq 2 \\
>2\end{array}$ & $\begin{array}{l}25(32.9) \\
51(67.1)\end{array}$ & $\begin{array}{c}36(19.5) \\
149(80.5)\end{array}$ & 0.020 \\
\hline $\begin{array}{l}\text { Pathological type } \\
\text { IDC } \\
\text { Other }\end{array}$ & $\begin{array}{c}68(89.5) \\
8(10.5)\end{array}$ & $\begin{array}{c}169(91.4) \\
16(8.6)\end{array}$ & 0.633 \\
\hline $\begin{array}{l}\text { Grade } \\
\text { I+II } \\
\text { III }\end{array}$ & $\begin{array}{l}38(53.5) \\
33(46.5)\end{array}$ & $\begin{array}{c}150(84.7) \\
27(15.3)\end{array}$ & $<0.001$ \\
\hline $\begin{array}{l}\text { ER } \\
\text { Negative } \\
\text { Positive }\end{array}$ & $\begin{array}{l}44(57.9) \\
32(42.1)\end{array}$ & $\begin{array}{c}47(25.4) \\
138(74.6)\end{array}$ & $<0.001$ \\
\hline $\begin{array}{l}\text { PgR } \\
\text { Negative } \\
\text { Positive }\end{array}$ & $\begin{array}{l}50(65.8) \\
26(34.2)\end{array}$ & $\begin{array}{c}58(31.4) \\
127(68.6) \\
\end{array}$ & $<0.001$ \\
\hline $\begin{array}{l}\text { HER2 } \\
\text { Negative } \\
\text { Positive }\end{array}$ & $\begin{array}{l}34(45.3) \\
41(54.7)\end{array}$ & $\begin{array}{c}116(64.8) \\
63(35.2)\end{array}$ & 0.004 \\
\hline $\begin{array}{l}\text { Ki67 } \\
\text { Low expression } \\
\text { High expression }\end{array}$ & $\begin{aligned} 6 & (8.2) \\
67 & (91.8)\end{aligned}$ & $\begin{array}{c}38(22.2) \\
133(77.8)\end{array}$ & 0.009 \\
\hline $\begin{array}{l}\text { Lymph nodes } \\
\text { Negative } \\
\text { Positive }\end{array}$ & $\begin{array}{l}42(57.5) \\
31(42.5) \\
\end{array}$ & $\begin{array}{c}54(31.2) \\
119(68.8)\end{array}$ & $<0.001$ \\
\hline $\begin{array}{l}\text { Chemotherapy cycle } \\
4 \sim \\
6 \sim \\
8 \sim\end{array}$ & $\begin{array}{l}12(15.8) \\
23(30.3) \\
41(53.9)\end{array}$ & $\begin{array}{l}43(23.2) \\
47(25.4) \\
95(51.4)\end{array}$ & 0.375 \\
\hline $\begin{array}{l}\text { Chemotherapy regimens } \\
\text { Anthracycline-based } \\
\text { Taxane-based } \\
\text { Combination of } \\
\quad \text { anthracycline and taxane }\end{array}$ & $\begin{array}{c}8(10.5) \\
53(69.7) \\
15(19.7)\end{array}$ & $\begin{array}{l}36(19.5) \\
53(28.6) \\
96(51.9)\end{array}$ & $<0.001$ \\
\hline $\begin{array}{l}\text { Baseline NLR } \\
<2.1 \\
\geq 2.1\end{array}$ & $\begin{array}{l}39(51.3) \\
37(48.7)\end{array}$ & $\begin{array}{l}91(49.2) \\
94(50.8)\end{array}$ & 0.755 \\
\hline $\begin{array}{l}\text { Baseline PLR } \\
<150 \\
\geq 150\end{array}$ & $\begin{array}{l}40(52.6) \\
36(47.4)\end{array}$ & $\begin{array}{c}121(65.4) \\
64(34.6)\end{array}$ & 0.054 \\
\hline
\end{tabular}

\section{METHODOLOGY}

It was a descriptive study conducted at the Department of Breast Center, Shunyi District Health Care Hospital for Women and Children of Beijing. The study was approved by the Research and Ethical Committee of the Hospital. From January 2009 to December 2017, a total of 303 consecutive women who had operable primary invasive breast cancer were treated with NAC at the Breast Center. All breast cancer cases were diagnosed by core needle biopsy (CNB) with a 16-gauge needle. Excluding those who received less than 4 cycles of treatment, 261 patients who had completed at least 4 cycles of NAC were enrolled in analysis ultimately. 
Table III: Multivariate unconditional logistic regression model for predicting PCR.

\begin{tabular}{|l|c|c|c|}
\hline & $\boldsymbol{\beta}$ & OR (95\%CI) & p-value \\
\hline Grade (III versus I+II) & 0.964 & $2.62(1.21-5.70)$ & 0.015 \\
\hline HR (negative versus positive) & 0.864 & $2.37(1.14-4.94)$ & 0.021 \\
\hline $\begin{array}{l}\text { Lymph nodes (negative versus } \\
\text { positive) }\end{array}$ & 0.824 & $2.28(1.13-4.62)$ & 0.022 \\
\hline HER2 (positive versus negative) & 0.761 & $2.14(1.04-4.39)$ & 0.038 \\
\hline $\begin{array}{l}\text { Chemotherapy regimens } \\
\text { (taxane-based versus combination) }\end{array}$ & 1.274 & $3.58(1.61-7.94)$ & 0.002 \\
\hline
\end{tabular}

Demographic characteristics, and clinicopathological data were obtained from in-patient medical record. Overweight was defined as a BMI of 24.0 to 27.9 and obesity as a BMI of 28.0 or higher according to Chinese standard. ${ }^{10}$ Ultrasound examination was routinely conducted before CNB, and tumor size was measured. $\mathrm{ER}, \mathrm{PgR}, \mathrm{HER} 2$ status and Ki67 index were determined by immunohistochemistry (IHC), and tumors with HER2 score 2+ were additionally evaluated by FISH, according to guidelines and expert consensus of China. ${ }^{11,12}$ ER or PgR was considered positive when $\geq 1 \%$ of tumor cells showed positive nuclear staining. The cutoff value of high expression for Ki67 was $\geq 20 \%$, as was discussed and in favour of by majority of the panellists on the $13^{\text {th }}$ St. Gallen International Breast Cancer Conference. ${ }^{13}$

Axillary lymph node status at baseline was evaluated through 2 steps prior to the beginning of NAC: firstly, ultrasound examination was used to scan the armpit area, and CNB or fine needle aspiration (FNA) was applied, if abnormally morphological lymph node was found; then, patients with negative result in CNB or FNA, as well as those without abnormally morphological lymph node in ultrasound examination, were recommended to consider sentinel lymph node biopsy (SLNB). Patients with positive result in CNB, FNA, or SLNB, and those rejected SLNB, would accept axillary lymph node dissection in surgery. Meanwhile, those without axillary lymph node involvement in SLNB would avoid dissection.

The cutoff values of NLR and PLR were determined considering median and the boundary value proposed in literature. ${ }^{9}$ Pathological complete response ( $p C R$ ) was defined as no residual invasive disease in either the breast or the axillary lymph nodes, with noninvasive breast residuals permitted, including ductal carcinoma in situ (ypTO/is ypN0) according to the $7^{\text {th }}$ Edition of AJCC Cancer Staging Manual. ${ }^{14}$

Two hundred and sixty-one patients received a median of 8 cycles of neoadjuvant chemotherapy (interquartile range, 6-8; range, 4 to 16 cycles). Treatment options were determined by molecular subtype, clinical stage, risk factors combined with full underlying evaluation for all patients, among whom, 44 patients were treated with anthracycline-based regimen only, such as CAF (cyclophosphamide, anthracyclines, and 5-fluorouracil), and AC (anthracycline, and cyclophosphamide); 106 patients were treated with taxane-based regimen only; for instance, TP (taxane, and carboplatin), and XT (capecitabine, and taxane); 111 patients were treated with combination regimens of anthracycline and taxane, including AT (anthracycline, and taxane), AC-T (anthracycline, and cyclophosphamide followed by taxane), and TAC (taxane, anthracycline, and cyclophosphamide). Patients with HER2 over- expression were recommended additional trastuzumab-targeted therapy.

The relative dose intensity was calculated according to the standard dose of different chemotherapeutics in the 2008 National Comprehensive Cancer Network (NCCN) guidelines. ${ }^{12}$

SPSS 16.0 software (SPSS Inc., Chicago, IL) was used to perform analysis. Categorical variables were described by percentage. The association of baseline characteristics with pathological response was analysed using Pearson's $\chi^{2}$ test. Factors achieving $p<0.1$ in univariate analysis were set as alternative variables, and unconditional logistic regression model was applied to determine whether a factor was independent predictor of $\mathrm{PCR}$ in multivariate analysis. Besides, chemotherapy cycle was also set as alternative variables according to the suggestion of oncologist in our department. Bivariate correlation was used to explore the correlation coefficient of ER and PgR, thereafter hormone receptor (HR) was used for replacement of ER and PgR. Thus, a total of 10 factors were included in the original regression model. Backward conditional method was used to filter variables, OR was calculated by the ratio of number of cases reached $\mathrm{pCR}$ divided by number of cases hadn't reached $p C R$ for patients with and without administration of trastuzumab. All statistical tests were two-sided, and statistical significance was defined as a p-value $<0.05$.

\section{RESULTS}

Two hundred and sixty-one operable primary breast cancer patients were included in this study. Patient characteristics were listed in Tablel.

After completion of NAC, $29.1 \%$ of breast tumors achieved pCR. The $\mathrm{pCR}$ rate differed significantly among different breast cancer subtypes $(P<0.001)$. Patients of TN subtype had the highest $P C R$ rate $(22 / 44,50.0 \%)$, followed by HER2-positive (41/104, 39.4\%), and the Luminal subtype showed the lowest pCR rate $(13 / 113$, $11.5 \%)$.

After univariate analysis, patients with smaller tumor size and higher grade were more likely to achieve higher rate of $p C R$ $(p=0.020, p<0.001)$. At the same time, ER- or PgR-negative tumors were more likely to respond to chemotherapy (both $p<0.001)$. However, tumors with HER2-positive had significantly higher $p C R$ rate $(p=0.004)$. Besides, expression of Ki67, status of underlying axillary lymph nodes, and taxane-based regimen were all significantly associated with $p C R(p=0.009, p<0.001$, $p<0.001)$. Notably, BMI and baseline PLR had nearly significant association with $p C R(p=0.093, p=0.054$, Table II).

Nine factors with $p<0.1$ in univariate analysis, including $B M I$, tumor size, grade, HR, HER2, Ki67 index, lymph nodes, chemotherapy regimens, and baseline PLR, together with chemotherapy cycles, were set as alternative variables, and unconditional logistic regression model was applied to explore independent factor of pCR. Finally, the multivariate analysis revealed that 5 factors were independent favorable predictors of pCR (Table III), which were high histological grade, negative HR status and lymph nodes, positive HER2 status, and taxane-based regimens.

A total of 104 patients had HER2-positive tumors, and 43 cases of them received trastuzumab-included NAC regimen, and $\mathrm{pCR}$ rate was $62.8 \%(27 / 43)$. On the other hand, the remaining 61 patients 
received NAC regimen without trastuzumab, and the $\mathrm{pCR}$ rate was significantly lower $(14 / 61,23.0 \%$ versus $62.8 \%, O R=5.67, p$ $<0.001$ ).

\section{DISCUSSION}

Neoadjuvant chemotherapy has been widely utilised in treatment of breast cancer, and pathological diagnosis after surgery contributed to evaluation of curative effect. Some clinicopathological characteristics and treatment related factors may play essential role in tumor response to preoperative chemotherapy.

Previous researchesshowed high histological grade and negative hormone receptor status were favourable predictive factors of $\mathrm{pCR},{ }^{15-17}$ and this study obtained the similar conclusions. Because of the correlation coefficient of ER and PgR had reached 0.773 in this study, multivariate analysis based on HR was conducted, and similar results as previous researches were acquired. However, we failed to demonstrate tumor size as an independent predictive factor of $\mathrm{pCR}$, which ascribed to the relative small sample size of this study compared to studies base on National Cancer Registry. ${ }^{18,19}$ The expression level of Ki67 as an independent predictive factor of pCR was also failed to be verified, ${ }^{20,21}$ which may be owing to the association between histological grade and Ki67. ${ }^{22}$ In this study, the proportion of patients with high expression of Ki67 was significantly higher in grade III group $(96.7 \%, 58 / 60)$ than that in grade I + I group (71.3\%, 134/188, p <0.001).

It has been widely recognised that lymph nodes involved after NAC play a key role in the prognosis of breast cancer patients. The response of axilla to NAC is an important component of pathological evaluation. In this study, negative axillary lymph nodes before treatment was proved to be a favourable predictive factor of pCR.

A study conducted in Turkey showed pCR rates in normal/underweight, overweight and obesity were $31.2 \%, 22.4 \%$, and $17.9 \%$ respectively, indicating a considerable trend towards significance; and obesity was an independent adverse predictor of pCR compared with normal/underweight patients. ${ }^{23}$ As is widely known, the BMI cutoff value for category of obesity extent is different between WHO and Chinese standards. ${ }^{10,24}$ In this study, the association between BMI and pCR under the above two standards was investigated respectively, which was found in neither univariate analysis nor multivariate analysis. Same is concluded by two meta-analyses. ${ }^{7,25}$

Peripheral blood was routinely tested for all breast cancer patients before initiation of treatment, and the association of baseline NLR/PLR and pCR was evaluated in this study. Regardless of the baseline NLR, similar rates of pCR were achieved. Inconsistent to previous research, ${ }^{9}$ patients with higher baseline PLR $(\geq 150)$ were more sensitive to NAC, and had corresponding higher pCR rate. So, further research on this field is needed.

Anthracycline-based and taxane-based systematic chemotherapy are both recommended by guidelines. Patients treated with anthracycline-based, taxane-based and combination regimens had accounted for $16.9 \%, 40.6 \%$, and $42.5 \%$, respectively. Taxane-based regimen showed a better performance in both univariate and multivariate analysis.

NAC combined with targeted therapy was preferred recommendation by guidelines for HER2-positive breast cancer. In this study, chemotherapy response of HER2-positive breast cancer was significantly affected by administration of trastuzumab. However, not every patient can afford administration of trastuzumab at her own expense. Therefore, government policy on medical insurance may also have an impact on the effectiveness of anti-cancer treatment.

The present study has several limitations. Being a retrospective study, histological grade, HER2 status and expression of Ki67 were unknown in $5.0 \%, 2.7 \%$ and $6.5 \%$ of the total patients respectively, which might influence the results.

\section{CONCLUSION}

The present study demonstrated that breast cancer patients with high histological grade, negative HR status and lymph nodes, positive HER2 status, as well as taxane-based regimens were more likely to achieve pCR. This may help in selection of candidates for NAC. However, extrapolation of the conclusion should be cautious, further research is warranted for verification of our findings.

\section{FUNDING:}

Clinical Key Specialist Construction Project of Shunyi District, Beijing (2015QJTS07).

\section{ETHICAL APPROVAL:}

The present study was approved prior to initiation of the research work by the Research and Ethical Committee of Shunyi District Health Care Hospital for Women and Children of Beijing, and conducted in accordance with the Principles of Helsinki Declaration (approval No. 2019-01 on $9^{\text {th }}$ October 2019).

\section{PATIENTS' CONSENT:}

As a non-interventional study, a waiver for informed consent was obtained from the Research and Ethical Committee of Shunyi District Health Care Hospital for Women and Children of Beijing, and all the data from patients were analyzed anonymously.

\section{CONFLICT OF INTEREST:}

Authors declared no conflict of interest.

\section{AUTHORS' CONTRIBUTION:}

YLv: Contributed to drafting the work, approval of the final version to be published and agreed to be accountable for all aspects of the work in ensuring that questions related to the accuracy or integrity of any part of the work are appropriately investigated and resolved.

YL: Contributed to the conception and design of this work.

WM, HF: Contributed to the interpretation of the data, and critical revision for important intellectual content.

\section{REFERENCES}

1. Kaufmann M, von Minckwitz G, Bear HD, Buzdar A, McGale P, Bonnefoi $\mathrm{H}$, et al. Recommendations from an international expert panel on the use of neoadjuvant (primary) systemic treatment of operable breast cancer: New perspectives 2006. Ann Oncol 2007; 18:1927-34.

2. Bardia A, Baselga J. Neoadjuvant therapy as a platform for drug development and approval in breast cancer. Clin Cancer Res 2013; 19:6360-70.

3. Wolmark N, Wang J, Mamounas E, Bryant J, Fisher B. Preoperative chemotherapy in patients with operable breast 
cancer: nine-year results from National Surgical Adjuvant Breast and Bowel Project B-18. J Natl Cancer Inst Monogr 2001; 30:96-102.

4. Jankowski C, Guiu S, Cortet M, Charon-Barra C, Desmoulins I, Lorgis $\mathrm{V}$, et al. Predictive factors of pathologic complete response of HER2-positive breast cancer after preoperative chemotherapy with trastuzumab: Development of a specific predictor and study of its utilities using decision curve analysis. Breast Cancer Res Treat 2017; 161:73-81.

5. Del Prete S, Caraglia M, Luce A, Montella L, Galizia G, Sperlongano $\mathrm{P}$, et al. Clinical and pathological factors predictive of response to neoadjuvant chemotherapy in breast cancer: A single center experience. Oncol Lett 2019; 18:3873-79.

6. Usiskin I, Li F, Irwin ML, Cartmel B, Sanft T. Association between pre-diagnosis BMI, physical activity, pathologic complete response, and chemotherapy completion in women treated with neoadjuvant chemotherapy for breast cancer. Breast Cancer 2019; 26:719-28.

7. Erbes $T$, Stickeler E, Rücker G, Buroh $\mathrm{S}$, Asberger J, Dany N, et al. BMI and pathologic complete response to neoadjuvant chemotherapy in breast cancer: A study and meta-analysis. Clin Breast Cancer 2016; 16:e119-132.

8. Graziano V, Grassadonia A, lezzi L, Vici P, Pizzuti L, Barba M, et al. Combination of peripheral neutrophil-to-lymphocyte ratio and platelet-to-lymphocyte ratio is predictive of pathological complete response after neoadjuvant chemotherapy in breast cancer patients. Breast 2019; 44:33-8.

9. Chen Y, Chen K, Xiao X, Nie Y, Qu S, Gong C, et al. Pretreatment neutrophil-to-lymphocyte ratio is correlated with response to neoadjuvant chemotherapy as an independent prognostic indicator in breast cancer patients: a retrospective study. BMC Cancer 2016; 16:320.

10. Chinese Obesity Task Force Data Analysis Collaborative Group. Predictive values of body mass index and waist circumference to risk factors of related diseases in Chinese adult population. Chin J Epidemiol 2002; 23:5-10.

11. Carlson RW, Moench SJ, Hammond ME, Perez EA, Burstein HJ, Allred DC, et al. HER2 testing in breast cancer: NCCN Task Force report and recommendations. J Natl Compr Canc Netw 2006; 4(Suppl 3):S1-s24

12. NCCN Clinical Practice Guidelines in Oncology for Breast Cancer (Chinese Version 1). 2008: p. 26,35-40.

13. Untch M, Gerber B, Harbeck N, Jackisch C, Marschner N, Möbus $V$, et al. 13th st. Gallen international breast cancer conference 2013: primary therapy of early breast cancer evidence, controversies, consensus - opinion of a german team of experts (zurich 2013). Breast Care (Basel) 2013; 8:221-9.

14. Edge SB, Byrd DR, Compton CC, Fritz AG, Greene FL, Trotti A.
AJCC Cancer Staging Manual. ed. $7^{\text {th }}$, Chicago: American Joint Committee on Cancer Executive Office, 2010.

15. Yao L, Liu Y, Li Z, Ouyang T, Li J, Wang T, et al. HER2 and response to anthracycline-based neoadjuvant chemotherapy in breast cancer. Ann Oncol 2011; 22:1326-31.

16. Kim WH, Kim HJ, Park HY, Park JY, Chae YS, Lee SM, et al. Axillary pathologic complete response to neoadjuvant chemotherapy in clinically node-positive breast cancer patients: A predictive model integrating the imaging characteristics of ultrasound restaging with known clinicopathologic characteristics. Ultrasound Med Biol 2019; 45:702-9.

17. Sasanpour P, Sandoughdaran S, Mosavi-Jarrahi A, Malekzadeh M. Predictors of pathological complete response to neoadjuvant chemotherapy in iranian breast cancer patients. Asian Pac J Cancer 2018; 19:2423-7.

18. Goorts B, van Nijnatten TJ, de Munck L, Moossdorff M, Heuts $E M$, de Boer $M$, et al. Clinical tumor stage is the most important predictor of pathological complete response rate after neoadjuvant chemotherapy in breast cancer patients. Breast Cancer Res Treat 2017; 163:83-91.

19. Livingston-Rosanoff D, Schumacher J, Vande Walle K, Stankowski-Drengler T, Greenberg CC, Neuman H, et al. Does tumor size predict response to neoadjuvant chemotherapy in the modern era of biologically driven treatment? A Nationwide study of us breast cancer patients. Clin Breast Cancer 2019; 19:e741-e7.

20. Jain P, Doval DC, Batra U, Goyal P, Bothra SJ, Agarwal C, et al. $\mathrm{Ki}-67$ labeling index as a predictor of response to neoadjuvant chemotherapy in breast cancer. Jpn J Clin Oncol 2019; 49:329-38

21. Tao M, Chen S, Zhang X, Zhou Q. Ki-67 labeling index is a predictive marker for a pathological complete response to neoadjuvant chemotherapy in breast cancer: A meta-analysis. Medicine (Baltimore) 2017; 96:e9384.

22. Oddó D, Pulgar D, Elgueta N, Acevedo F, Razmiliz D, Navarro $\mathrm{ME}$, et al. Can histological grade and mitotic index replace ki67 to determine luminal breast cancer subtypes? Asian Pac J Cancer Prev 2018; 19:179-83.

23. Karatas F, Erdem GU, Sahin S, Aytekin A, Yuce D, Sever AR, et al. Obesity is an independent prognostic factor of decreased pathological complete response to neoadjuvant chemotherapy in breast cancer patients. Breast 2017; 32:237-44.

24. WHO. Obesity and overweight. http://www.who.int/western pacific/health-topics/obesity. (Accessed on 3/18/2020)

25. Warner ET, Ballman KV, Strand C, Boughey JC, Buzdar AU, Carey LA, et al. Impact of race, ethnicity, and BMI on achievement of pathologic complete response following neoadjuvant chemotherapy for breast cancer: a pooled analysis of four prospective Alliance clinical trials (A151426). Breast Cancer Res Treat 2016; 159:109-18. 